only for biological work, but also for meteorology, climatology, astronomy, etc.

Among the demonstrations, one by A. N. Richards and J. T. Wearn, of Philadelphia, attracted much attention. They showed how to collect glomerular filtrate by insertion of a very fine capillary into Bowman's capsule in the frog. The crowded laboratory must have increased the difficulties of this very delicate operation. Prof. Richards subsequently explained how the minute volume of fluid was analysed by the nephelometric methods of his namesake, the chemist. The filtrate is rich in chlorides which must be re-absorbed in the tubules, and hence a decision is arrived at with regard to rival theories of urinary secretion. Similarly, Bloor's nephelometric phosphorus determination, modified by $\mathrm{H}$. Winterstein, of Rostock, enabled the latter to investigate the phosphorus metabolism of the central nervous system of the frog; the phosphatides here play a considerable part.

H. J. Hamburger and R. Brinkman, of Groningen, claim that the nervous stimulation of the heart sets free substances which influence the contraction of the stomach and gut in the same way as if the nerves of these organs are stimulated electrically; they term this humoral transmission of nervous impulses.

Papers of methodological importance were communicated by A. Kossel, of Heidelberg, who has discovered in the dinitronaphtholsulphonic acid of naphthol yellow a reagent for the quantitative precipitation of arginine and for the isolation of many other bases, and by E. London, of Petrograd, who described a new method for investigating intermediate metabolism, consisting in the introduction of permanent metal cannulæ into deep-seated abdominal blood vessels.

Owing to the circumstance that a conference on the physiological standardisation of drugs met under the auspices of the League of Nations at Edinburgh just before the congress, pharmacology was well represented. At the congress, J. J. Abel and C. A. Rouiller, of Baltimore, described the further purification of the oxytoxic principle of the pituitary, which they have now obtained as a substance which is rooo-1250 times as active as histamine phosphate on the guinea-pig's uterus; the product also possesses powerful pressor and diuretic properties.

W. E. Brown and V. E. Henderson, of Toronto, find that ethylene will produce complete surgical anæsthesia, being more potent and in other ways preferable to nitrous oxide.

During the congress a number of important cinematographic demonstrations were given; perhaps the most interesting was by A. Krogh, of Copenhagen, which showed, under great magnification, the effect of various agents on capillary circulation (this film should prove of immense value in teaching large classes).

In connexion with the congress a Harvey medal, the work of Mr. Pilkington Jackson, the Edinburgh sculptor, was given to every member, and the University of Edinburgh conferred honorary degrees on eight distinguished foreign physiologists who were present, namely, Prof. F. Bottazzi, professor of physiology, University of Naples; Prof. W. Einthoven, professor of physiology, University of Leyden; Prof. W. H. Howell, professor of hygiene, Johns Hopkins University, Baltimore; Prof. J. E. Johansson, professor of physiology, University of Stockholm; Prof. A. Kossel, professor of physiology, University of Heidelberg; Prof. H. H. Meyer, professor of pharmacology, University of Vienna; Prof. I. P. Pawlow, professor of physiology, University of Petrograd; and Prof. Ch. Richet, professor of physiology in the Faculty of Medicine, Paris.

\title{
A Seventeenth Century University of London.
}

FVERY one knows that London was the last great capital city to be provided with a University. The reason for this is not obvious, but the fact remains that after the failure of Sir Thomas Gresham's great aspiration in the seventeenth century, the mere idea of a University seems to have been dropped until it was revived by the Benthamites in the nineteenth century. But not altogether : a solitary enthusiast now and again raised his voice. In $I 647$ there was a curious proposal launched in a pamphlet, now extremely rare, for remedying this deficiency. The proposal came to nought, like many educational projects, not only, we may surmise, because the country was in the grip of the Civil War, but, as will appear, by reason of certain difficulties inherent in the scheme. The title of the tract, or rather part of the title-for it is a true child of the seventeenth century, when long titles were the vogue-is " Motives grounded upon the Word of God, and upon Honour, Profit, and Pleasure for the present Founding an University in the Metropolis London, ...." and the author chose to be known as " a True Lover of his Nation, and especially of the said City."

The True Lover is manifestly a Puritan, and his main concern is with the shortness in the supply of preachers of whom he estimates that we want more than 20,000, "and are hopeless of supply, without other provision than yet we have." The old universities, even at their prime, could not bring forth such numbers. Now was the golden opportunity for London to remedy this lamentable defect " when so many great houses may be had and made Colleges of, with so little alteration, and Pauls Church and London-House be the publike Schooles." Teachers were to be had on as easy terms as buildings: "by reason of the Warres in other Countries, you may now have the choicest of their Professours of the Arts."

But the True Lover's financial plan displays greater optimism than knowledge of human nature warrants. If every sincere Christian in London gave up one meat meal a week it would be possible to maintain, he thinks, twenty thousand "poore Schollars," and a similar abstention throughout the Kingdom an hundred thousand. This greater number by no means dismays the True Lover; on the contrary, it stirs his enthusiasm. After a general course of military training, twenty thousand of the " choycest" would be selected as ministers, the remainder being " imployed in Trades, or Navigation and show themselves for the defence of this country Lions on the Land, and Dolphines on the Seas." The elect would also "Discipline their Parishes and put all England in Israels posture so that we might be a Nation of Souldiers and defend our Religion both with Divine arguments and (if need required) with corporall Armes also.'

If the True Lover had read Milton's famous Tractate on Education, published three years earlier, he had not been impressed by it, nor had he apparently breathed any of the ideas which were a few years later to bring about the first meetings of the nascent Royal Society. His notions of curricula may be described as humanistic, coloured with a pronounced utilitarianism. Three colleges were to house the hundred thousand. In one nothing but Latin was to be spoken, and in two years the scholars would thus be able to speak as good Latin as they do English. "How easily afterwards," he exclaims, "would they 
attaine the Italian, French and Spanish Tongues, and in Merchandizing be fit to negotiate with the greatest Princes." In a second College nothing would be spoken but Greek, and in a third Hebrew. This would attract all " forraigne Protestants of work in this westerne World," as well as the Jews" "whose conversion is now at hand."

The vision of a truly Puritan Paradise opens up. "If London were an University, such, pluming the Crest of this Royall City, would cause it to present a more glorious aspect than all the lofty. Cypresses in Constantinople doe unto all that approach unto it: yea, all the yeare long cause London to resemble Jerusalem in the Feast of Tabernacles." Not only would there be a chaplain in every house of the nobility (and even "the Citizens carry one sometimes"), but every godly merchant might have a graduate in his ship, and "Sea-men (generally so prophane) " might become Saints and " their masters goods prosper in their hands."

That there will be objections from Cambridge and Oxford (the order of precedence is his and prompts a conjecture as to the True Lover's upbringing) is foreseen, but these, it can well be imagined, do not daunt such a buoyant optimism. Your True Lover, if he is worthy of the name, has as little difficulty with objections as with finance. Thus there are nine answers to the three objections " weak, weaker, weakest"), not any of which are objections founded upon such base things as accommodation and finance. Perhaps, however, it was this sort of objection which prevailed with the Lord Mayor and his colleagues (to whom "Motives" are presented), and, as we know, the True Lover's University did not build Jerusalem in London. Which, perhaps, is just as well.
E. D.

\section{Immigration and Degeneracy in the United States. ${ }^{1}$}

\section{TH}

HE United States Government is taking measures to control immigration, so as to ensure, so far as is possible, that undesirables of all sorts shall be excluded. The present publication, which is the statement of Dr. Harry H. Laughlin made before the Committee on Immigration and Naturalisation of the House of Representatives, is witness to its activity in this direction. By estimating the actual and predicted proportions of various sorts of degeneracy contributed by the various stocks that enter the United States, it is possible, by excluding immigrants from those foreign countries that contribute more than their share, to ensure that the healthiest possible stocks only are admitted.

The statement of Dr. Laughlin covers feeblemindedness, insanity, criminality, epilepsy, inebriacy, leprosy, tuberculosis, blindness, deafness, deformation, and dependency. It is found that each of these forms of degeneracy demand distinct methods of treatment. For example, it is comparatively easy to control feeble-mindedness, for it manifests itself early in life. Therefore it is found that the native white population contributes, proportionally, more than the immigrant white to the feeble-minded part of the population. On the other hand, insanity, which manifests itself much later in life, is not so easy to diagnose in the immigrant, with the consequence that the immigrants of the present generation have a higher incidence of mental instability than is possessed by the foundation families. Therefore it

${ }^{1}$ Analysis of America's Modern Melting Pot: Hearings before the Committee on Immigration and Naturalisation, House of Representatives, Sixty-seventh Congress, Third Session, November 21, 1922. Statement by Harry H. Laughlin. (Serial 7-C.) Pp.723-83r. (Washington: Government Printing Office, r923). is proposed that immigrants should come of families with no record of insanity.

The case of crime is interesting. Those countries that have contributed least to the criminal population of the United States are Great Britain, Scandinavia, Ireland, Germany, and the Netherlands ; i.e. precisely those that have contributed the foundation stocks. The Southern European countries have contributed a far larger proportion, and this is probably due, in the opinion of Dr. Laughlin, to a change in social environment, with a consequent social maladjustment. Since criminalistic tendencies show themselves early in life, it has been possible to exclude this type with a considerable degree of success.

The analysis of figures has made it possible to reach some interesting conclusions with regard to the contributions to degeneracy made by the different constituent elements of the population of the United States, and it is evident from this report that before long we shall know much more than we do at present about the problem of degeneracy. One definite conclusion seems to have been reached by Dr. Laughlin; he states that " custodial inadequates are for the most part recruited from a relatively small portion of the families of the whole population. This means that social inadequacy is not a result of accident or bad environment, but that primarily most custodial inadequacy is founded upon degenerate inheritance."

The ultimate effects of the prosecution of a thoroughgoing policy of immigration control will be far-reaching; for the United States will be able to absorb the healthy stocks, and to reject the unhealthy, thus greatly benefiting itself at the double expense of European countries.

\section{Fire Hazards and Fire Extinction on Oilfields.}

$\mathrm{T}$ $\mathrm{HE}$ subject of fire-risk, prevention and extinction on oilfields is one which the public as a whole tends to take very much for granted, only being stirred to interest by press reports of oil-well fires such as occurred in Trinidad some two years ago, when thousands of pounds' worth of damage was done, or by more serious disasters on some of the American fields, involving the loss of many lives. On the other hand, those concerned with the actual control of oilfields, if not the employees themselves, are very much alive to the ever-present danger of a conflagration arising from the high degree of inflammability of petroleum and its products, and they know, usually only too well from experience, that oil-fires, from the inherent nature of the materials involved, are by far the most difficult to combat successfully.
Prof. J. S. S. Brame chose this subject as the theme of his valedictory address to the Institution of Petroleum Technologists recently, and in view of the rapid and generally unappreciated evolution of modern methods of oil-fire extinction, especially as practised in America, his dissertation was particularly welcome. It certainly stimulated members of his audience to a keener perception of the risks run by those engaged in all branches of the industry, without in any sense being either sensational or alarming.

As with other undesirable evils, prevention being better than cure, the greatest possible care is taken nowadays to meet, by precautionary measures, the contingencies of oil-well and oil-tank fires. Unfortunately, one of the chief causes, lightning, is extremely 